\title{
Minutes of the 33rd General Assembly of the European Association for the Study of Diabetes
}

\section{Held in Call C1 of the Helsinki Fair Center, Helsinki, Finland, 22 nd July 1997 from 12.15-13.30h}

\author{
Present: Drs. M Berger (President) \\ UJ Eriksson (Honorary Secretary) \\ E Ferrannini (Editor-in-Chief, \\ Diabetologia) \\ R Heine (Honorary Treasurer)
}

and 145 members

In welcoming everyone to the General Assembly Prof. Berger explained the decision to move the General Assembly to the lunch time in order to attract more members to attend. Last year this change had been a big success. As the time was very limited, Dr. Berger asked everybody to bear this in mind when giving their reports.

Then the President reported that Drs E. F. Pfeiffer, A. Loubatières and $H$. Rifkin had died in the past year, the two first mentioned members having been founding members of the EASD. All members stood in silence in their memory.

\section{Minutes, 32 nd General Assembly 1996}

When no objections were received, Dr. Berger and Dr. Eriksson signed the minutes as a correct record.

\section{Reports}

a) President: Reporting on the EASD activities, the President began by expressing his deep thanks to Dr. G. Schernthaner for having organised a very successful Annual Meeting in Vienna. His scepticism towards the size of the meeting had been dissoluted by the very positive feedback received from the participants.

Then the President thanked Novo Nordisk for their traditional sponsorship of the Abstract Volume and the Poster Boards.

After the Annual Meeting in Vienna, the EU-Sub-Committee had issued the brochure "European Dimension of Diabetes Research" which was sent to all Members of the EU-Parlia- ment. This was followed by a Symposium called "Diabetes in Europe - A major health problem and research opportunity" on March 6, 1997 to which the members of the EU-Parliament had been invited. The whole day symposium was co-chaired by Mr. B. Hansen, Director of the Life Sciences and Technologies Programme and included all disciplines centred around diabetes. The lecturers and chairmen represented every country of the European Community. Although not many people had attended this initiative, it had been a success. Dr. Berger had been invited to a symposium in Brussels in June 1997 at which occasion he was made aware that diabetes was listed as a core activity in the proposal of the new framework. Diabetes was mentioned under age-related and under metabolic diseases. Dr. Berger hoped that this proposal would finally be accepted by the European Parliament as diabetes could then be identified as a health problem in the future.

Then the President reported on the first clinical Scientists Training Course which had taken place in Perugia, Italy. 19 members had attended this course; this time no American member was present. Dr. Berger appealed to the members to send more applications to this one-week course which was especially organised for young members offering them a fantastic training opportunity. The next course would be held by Dr. Åke Lernmark in Seattle; information sheets were handed out at the EASD Secretariat.

This year's Oxford Workshop was entitled "Diabetic Eye Disease" and would be held 11-14 September 1997. 20 researchers with each one nominating a fellow were invited to this meeting. This activity was sponsored by Hoechst Marion Roussel who had also sponsored the Minkowski Prize. The Claude Bernard award had been supported by the Paul Neumann Fondation. Dr. Berger thanked the companies for their continued support. Further prizes sponsored by companies were the Eli Lilly / EASD Research Fellowship (US\$35,000), the Glaxo Wellcome / EASD Burden of Diabetes Research Fellowship $(£ 20,000)$ and the EASD-Bayer Travel Fellowships for young Scientists (each $£ 4,000$ ) for which the President expressed the Association's thanks.

Then he reported on new sponsorships which had been achieved. Novo Nordisk Germany and Austria would support the EASD Solidarity Fund with an amount of DM 60,000 annually. The EASD Scientists Training Course had been supported with $\$ 35,000$ by Eli Lilly in 1997 . This sponsorship would be increased to $\$ 70,000$ annually for the years 1998-2000. A new award which had been discussed at the Ex- 
ecutive Committee Meeting would be financed by the company Sankyo. The DM 50,000 award to which no lecture was connected would be called "The EASD / Sankyo Insulin Resistance Project Award". Dr. Berger expressed the Association's deep gratitude for these generous sponsorships.

The Fourth Industry Liaison Meeting had taken place in a cordial and friendly atmosphere in February 1997. All EASD Supporting and Associate Members had been invited to this forum of interactions and discussions. At this meeting the decision was taken not to print any sponsorship from pharmaceutical companies below symposia, lectures or oral sessions in the Final Programme, but to have a list of all sponsorships received either at the front or at the back of the Programme.

A close co-operation with the IDF had been achieved with the EASD handling the abstracts for the congress. Of the 2,800 abstracts received $96 \%$ had been accepted.

Dr. Berger informed the General Assembly that new contacts would be established to the EASD Liaison Officers with regards to their objectives and term of office.

No questions or comments followed the President's report.

b) Honorary Treasurer: This was Dr. Heine's first report presented to the General Assembly and he started by explaining the income side of the EASD accounts. Membership fees had decreased slightly due to the possibility offered to members to pay for two years since 1995. Donations were less compared to 1995 as not all sponsorships for the Annual Meeting Symposia had been received. The surplus of the 1996 Annual Meeting had been higher than in the year before, but Dr. Heine pointed out that no surplus would be received this year. The generally lower interest rates had led to a lower income of interest. A payment from the JDFI and the registration fees were included in the figure of the Scientists Training Course.

On the expenditure side the items salaries, rent, post, phone and printing costs had nearly all remained unchanged. Travel expenses had decreased, while office costs including bank charges had increased because bank charges had been procentually higher which was in line with membership fees being paid for two years. More extra help had been necessary for the IDF abstract handling and the increase of the item 'legal cost and accounting' reflected the work of the accountant who had presented three years of accounting to the German Inland Revenue. In return the EASD had received the valuable statement which confirmed that the EASD had been a non-profit organisation in the past years. Annual Meeting expenses had risen with a higher number of invited speakers. The amount spent on Travel and Stayment Grants went down although all applications which had met the requirements had been accepted.

The accounts as of 31 st December 1996 showed a very healthy state which was mainly due to the surplus received from the Vienna Meeting. However, Dr. Heine pointed out that the EASD could expect expenses in the range of $£ 700,000$ in 1997 when no income from an Annual Meeting would be recorded.

Dr. P. Lefèbvre asked the Honorary Treasurer if the expenses of the EU-Meeting were included in the estimation of costs as that would otherwise needed to added. Dr. Heine confirmed that this item of approximately DM 100,000 had not been included in the figure.

When no further questions arose, Dr. Berger asked the Honorary Auditors for their confirmation of correctness. Dr. Pipeleers had forwarded his approval in writing to the EASD. After Dr. P. J. Guillausseau gave his approval, the General Assembly unanimously accepted the accounts.
Then the President informed the General Assembly that the EASD Council had discussed the possibility of establishing an EASD-Fund. By this the EASD could protect its non-profit status, would gain some independence and would also ensure stability of the EASD financial situation.

c) Editor-in-Chief, Diabetologia: Dr. Ferrannini started his report by thanking the editorial staff, Ms Sarah Hills (managing editor), Ms Caterina Baldocchi (secretary) and the extra help Ms M. Salvioni Reeder and Ms Alison Frank for their efficient work. He underlined that the relationship with the Deputy Editors Drs. P. A. Halban and H. Häring had been very efficient and smooth.

As of 31.12.96 the retiring Associate Editors were replaced by P. Froguel, E. Gale, M. Laakso, Y. Le Marchand Brustel, M. Prentki, E. Schleicher and M. Sternberg. The new Advisory Board Members were: AJM Boulton, N. Hotta, E. Shafrir, R. Williams and J-W. Yoon.

A total of 740 manuscripts had been received in 1996 of which 88 had been sent from UK, now in leading position, followed by Japan, the USA and Italy. Within the countries who contributed more than 10 manuscripts, Sweden, Denmark and Australia increased their submissions, while the number of manuscripts coming from Germany and France had decreased. The acceptance rate had dropped from $23 \%$ in 1995 to $22 \%$. Acceptance rate for Rapid Communications increased from $27 \%$ in 1995 to $31 \% .15$ Review articles and 22 For Debate articles were received of which 8 and 14 respectively had been accepted for publication. In addition, two Editorials had been published and of the 93 letters received, 33 had been printed.

The average number of days for Associate Editors' reports and for time needed to make an initial decision on acceptance/rejection had once again decreased to 50/51 days. Springer had also decreased the time for publication from 121 days in 1995 to only 83 days in 1996 . Thus the overall time interval from receipt to publication had decreased from 8.7 months in 1995 to an all-time nadir of 6.2 months in 1996.

In December 1996 a special issue on the vascular complications of NIDDM had been published, with Dr. C.-E. Mogensen as Guest Editor-in-Chief. A supplement based on the 1995 and 1996 joint EASD-JDFI Oxford Workshops was published in July 1997 with Drs KGMM Alberti and J.D. McGarry as Guest Editors. The Guest-Editors of the supplement based on the JDFI Fourth World Conference on Diabetes Research which would be published in October 1997 were Drs P. A. Halban, P. Czernichow, J.D. McGarry and A. Naji.

The impact factor for 1996 (latest quote available) had been 5.376 (4.525 in 1995) for Diabetologia and 6.248 (1995) for Diabetes.

Dr. Berger expressed the Association's deep thanks to Dr. Ferrannini for the four extremely successful years which made the journal Diabetologia very attractive to diabetologists. The President extended his thanks to the Editorial staff, especially to Ms Sarah Hills and to the staff at Springer-Verlag who had also contributed to the fantastic decrease in publication time.

As it was requested by a member, Dr. Ferrannini gave the definition of the impact factor. Dr. P. Lefèbvre expressed his personal thanks to the Editor-in-Chief and pointed out the tremendous effort of Springer with regards to the abstract volume.

Dr. R. Korec remarked with regret that no special article on the 75 th anniversary of the discovery of insulin had been published.

d) Honorary Secretary: Dr. Eriksson informed the General Assembly that this year his main task had been the allocation of 
money. Although no EASD Meeting was held, 100 Travel Grants and 10 Stayment Grants had been accepted, amounting to a total of DM 100,000. Then Dr. Eriksson announced the 1997 prize winners: Dr. Philippe Froguel (F) had been awarded the Minkowski Prize, Dr. Hans-Henrik Parving (DK) had received this year's Castelli Pedroli Prize and the Albert Renold Fellowship had been given to Dr. Antti Virkamäki (FIN). The Eli Lilly / EASD Research Fellowship in Diabetes and Metabolism had been awarded to Dr. Fiona Gribble (UK) and the Glaxo Wellcome / EASD Burden of Diabetes Research Fellowship had been given to Dr. Josefa Fernández Alvarez (E). Out of the 8 available EASD-Bayer Travel Fellowships for Young Scientists, Drs Christian Weyer (D), Matthias Meier (D), Ilse Rooman (B), Karin Ferber (D) and Aterios Kukuvitis (GR) had each been granted a $£ 4,000$ travel fellowship. The Honorary Secretary repeated the President's appeal for more applications.

In connection with the 34 th EASD Annual Meeting in Barcelona in 1998 the DOIT, Lipoprotein and Hypertension in Diabetes Study Groups will give their presentations. Dr. Eriksson said that he would contact all EASD Study Groups to get their most recent reports and lists of board members which would then be published in the EASD News Section of Diabetologia. Regarding the next EASD Annual Meeting, he asked the membership for suggestions on how to improve the Meeting's scientific value.

The President thanked Dr. Eriksson for his brief report and added that Dr. C. Wollheim had been appointed as 1998 Claude Bernard Lecturer.

\section{Elections}

a) President 1998-2001: The election of Dr. J. Nerup as President-elect was unanimously approved.

b) Editor-in-Chief, Diabetologia: The search sub-committee had evaluated the four applications received for this position. Their decision to elect Dr. W. Waldhäusl had been approved by the EASD Executive Committee and the Council. The General Assembly also approved this election.

c) Adjunct-Honorary Secretary: The election of Dr. Massimo Porta was unanimously accepted by the General Assembly.

d) Council Members 1998-2001: Drs. P. R. Flatt (UK), R. Holl (D), M. Marre (F) and E. Van Obberghen (F) were unanimously elected by the General Assembly in place of retiring Council Members Drs M. Benroubi, R.W. Bilous and H. Yki-Järvinen.

\section{Postgraduate Education-Sub-Committee}

Dr. Boulton reported on four successful PGECS-Courses which had been held between September 1996 and June 1997. One Course had taken place in September 1996 in Prague, following the EASD Annual Meeting in Vienna at which a total of 100 diabetologists, nurses and general practitioners participated.

The course which was held on Malta in February 1997 had been the first EASD PGESC Course held in the Mediterranean region. General practitioners and nurses from Malta, but also physicians from Syria, Jordan, Algeria, Morocco, Libya and Cyprus participated in this interactive and successful course.

The PGESC Course held in Graz in March 1997 had attracted so many participants that it was likely to be organised again in 1998.
Finally, after the preparations had been extremely difficult, a course had been held in Lviv, Ukraine, in April 1997 and had passed off without any major problems. Dr. A. Serhiyenko who had organised this course was thanked for his help and assistance. The course had been a big success.

Looking at future courses, Dr. Boulton reported on the organisation of a course in Turkey in September 1997. In conjunction with the "Mediterranean Group for the Study of Diabetes" and co-chaired by Drs G. Crepaldi and AJM Boulton, this course would concentrate on NIDDM and its complications. Emphasis would be placed upon community management and team approach.

Still under discussion were the following courses for 1998: a) PGESC Course in Krakow, Poland, co-organised by Dr. J. Sieradzki and members of the PGESC; $b$ ) another course in Graz in March 1998, again organised by Dr. T. Pieber and colleagues in conjunction with PGESC officers; c) initial discussions had taken place with Dr. M. Pinget from Strasbourg to run a course in France later in 1998.

Finishing his report, Dr. Boulton expressed his thanks to Dr. J. Skrha, Secretary of the PGESC.

The President thanked Dr. Boulton for his successful work which no longer concentrated on the east European region but also involved the south and the Mediterranean area. Dr. Berger informed the General Assembly that a budget of $£ 15,000$ for the year 1997 had been approved by the Executive Committee Members at their meeting in March 1997.

\section{Study Groups}

The President informed the General Assembly that the Study Group 'Psychosocial Aspects of Diabetes' had been endorsed. Regarding the approach of establishing a 'Diabetic Foot' Study Group, Dr. Berger reported that draft bye-laws had been received and an announcement had been placed in the EASD News Section. Many members had already been in contact with Dr. Boulton who was to be the chairman of the group. A first meeting was planned to be held around the Annual Meeting in 1998.

The President of the Epidemiology Study Group asked for the EASD's involvement regarding a re-classification of Diabetes. 20,000 individuals had been investigated and the evaluation had shown that it was necessary to set new criteria. The ADA had already acted to this by changing the criteria in the USA.

Dr. Berger agreed that this was an important issue and that it should be published in the EASD News Section. However, the EASD was based on individual membership and therefore this matter should rather ask for the Epidemiology Study Group's activity. In addition, it was the EASD's policy not to publish any statement or guideline. However, a report in the News Section would be very welcome.

Dr. P. Björntorp announced the establishment of an 'International Obesity Task Force' resulting from the increasing number of obese patients in general but especially in connection with the disease diabetes. A closer collaboration with diabetologists could help both sides. The presented leaflet should be printed as an announcement in the EASD News Section.

\section{Honorary Membership}

The President introduced Dr. E. Shafrir who had been nominated as new Honorary Member by the EASD Council. In 1974 Dr. Shafrir had organised the EASD Annual Meeting at 
very short notice after the Local Organisers in Athens had to cancel the Meeting. Beside this, Dr. Shafrir was well-known for his knowledge in Diabetes and his research in metabolism. The General Assembly unanimously elected Dr. Shafrir as Honorary Member.

\section{Any other Business}

The President thanked the retiring Vice President Dr. P. Passa from France and the retiring Council Members Drs. J.S. Christiansen, R. Gomis, I. Kalits and G. Schernthaner for their faithful service to the EASD. He welcomed the incoming officers, Dr. G. H. Tomkin (Ireland) as Vice President, Dr. M. Por-

Table 1. Consolidated accounts for the year ended

\begin{tabular}{|c|c|c|}
\hline Average Exchange rate DM/£ & $£ 2.262$ & $£ 2.3478$ \\
\hline Income & 1995 & 1996 \\
\hline Membership fees incl. Diabetologia & 367,079 & 334,351 \\
\hline Donations & 181,434 & 93,383 \\
\hline Annual Meeting Surpluses & 137,317 & 823,254 \\
\hline Bank interest & 36,743 & 26,460 \\
\hline Scientinsts Training Course & 2,632 & 9,595 \\
\hline Total & 725,205 & $1,287,043$ \\
\hline Expenditure & 1995 & 1996 \\
\hline Salaries & 105,306 & 106,612 \\
\hline Rent & 7,298 & 7,124 \\
\hline Post, Phone/Fax, Printing & 24,201 & 20,417 \\
\hline Travel Expenses & 34,676 & 17,705 \\
\hline Office Costs, incl. Bank charges & 27,357 & 33,872 \\
\hline Extra office help & 1,139 & 3,791 \\
\hline Legal cost and accounting & 698 & 8,621 \\
\hline Annual Meeting expenses & 83,126 & 106,084 \\
\hline $\begin{array}{l}\text { Free loans to Local Organisers } \\
\text { of the years } 1993,1994,1995\end{array}$ & 50,000 & 50,000 \\
\hline Travel and Stayment Grants & 55,472 & 36,683 \\
\hline Prizes and Fellowships & 67,110 & 67,268 \\
\hline $\begin{array}{l}\text { Donation to country hosting } \\
\text { the Annual Meeting }\end{array}$ & ond & 32,863 \\
\hline Donation others & 12,500 & 4,824 \\
\hline Diabetologia subscriptions & 257,956 & 249,067 \\
\hline Editorial Office & 64,788 & 52,230 \\
\hline Other items incl. PGESC & 5,722 & 5,062 \\
\hline Scientists Training Course & 34,195 & 33,463 \\
\hline Total & 831,544 & 835,686 \\
\hline
\end{tabular}

Year end exchange rates:

1995: £-DM 2.2205 Sfr - DM 124.64

1996: $£$ - DM 2.6267 Sfr - DM 115.00 ta (Italy) as Adjunct Honorary Secretary and the new Council Members Drs. T. Halmos (Hungary), M. Hod (Israel), D. Koev (Bulgaria) and I. Valverde (Spain).

Dr. Berger expressed his thanks to Dr. Jörgens and to the secretaries of the EASD office Mrs. M. Hata, Ms. K. Page and Mrs. R. Sautter for all the help he had received during the year. He congratulated Dr. C. Hellerström on his 65 th birthday and informed the EASD members that Dr. Hellerström had received the Albert Renold Medal on the occasion of his retirement. The President also thanked Dr. G. Schernthaner for his outstanding devotion to the 32nd EASD Annual Meeting. He was asked to the podium where he was given the Albert Renold Medal.

At $13.30 \mathrm{~h}$ the General Assembly was closed by the President.

Table 2. Future EASD Annual Meetings

\begin{tabular}{lll}
\hline 1999 & 28 Sept -2 Oct. & Brussels, Belgium \\
2000 & $17-21$ September & Jerusalem, Israel \\
2001 & & Birmingham, UK \\
2002 & & Budapest, Hungary \\
2003 & & IDF Congress, Paris, France \\
2004 & & Munich, Germany \\
\hline
\end{tabular}


Table 3. Breakdown of membership by country compared to previous years (as of 31st December):

\begin{tabular}{lrrrrrrrrrr}
\hline & 1996 & 1995 & 1994 & 1993 & 1992 & 1991 & 1990 & 1989 & 1988 \\
\hline Albania & 1 & & & & & & & & \\
Algeria & 13 & 2 & 4 & 4 & 1 & - & 1 & 1 & - \\
Argentina & 8 & 7 & 8 & 7 & 6 & 6 & 6 & 8 & 8 \\
Armenia & 1 & - & - & - & - & - & - & - & - \\
Australia & 79 & 69 & 62 & 66 & 61 & 54 & 52 & 48 & 42 \\
Austria & 112 & 70 & 60 & 54 & 57 & 37 & 34 & 39 & 34 \\
Azerbaijan & & & & & & & & &
\end{tabular}

(CIS)

Bahrain

$\begin{array}{lrrrrrrrrr}\text { Bangladesh } & 18 & 14 & 6 & 3 & 3 & 1 & 1 & 1 & 1\end{array}$

$\begin{array}{llllllllll}\text { Belgium } & 153 & 144 & 133 & 154 & 161 & 140 & 138 & 140 & 111\end{array}$

$\begin{array}{lrrrrrrrrr}\text { Bolivia } & - & 1 & 1 & - & - & - & - & - & - \\ \text { Brazil } & 20 & 13 & 12 & 10 & 9 & 9 & 9 & 9 & 4\end{array}$

$\begin{array}{lllllllllr}\text { Brazil } & 20 & 13 & 12 & 10 & 9 & 9 & 9 & 9 \\ \text { Bulgaria } & 66 & 62 & 67 & 59 & 36 & 32 & 24 & 19 & 16\end{array}$

Byelorussia

$\begin{array}{llllllllll}(\text { CIS) } & 7 & 3 & 4 & 1 & - & 1 & - & - & - \\ \text { Cameroon } & 1 & - & - & - & - & - & - & - & -\end{array}$

$\begin{array}{llllllllll}\text { Canada } & 34 & 38 & 37 & 36 & 32 & 33 & 33 & 35 & 26\end{array}$

$\begin{array}{lllllllllll}\text { Ceylon } & 1 & 1 & 1 & 1 & 1 & 1 & - & - & -\end{array}$

$\begin{array}{llllllllll}\text { Chad } & 1 & 1 & - & - & - & - & - & - & - \\ \text { Chile } & 4 & 5 & 4 & 3 & 3 & 4 & 4 & 4 & 3\end{array}$

$\begin{array}{llllllllll}\text { China } & 1 & 1 & 2 & 1 & 1 & 2 & 2 & 2 & 1\end{array}$

$\begin{array}{llllllllll}\text { Columbia } & 3 & 2 & 2 & 1 & 1 & - & 1 & 1 & 1\end{array}$

$\begin{array}{llllllllll}\text { Costa Rica } & - & - & 1 & - & 1 & 1 & 1 & 1 & -\end{array}$

$\begin{array}{llllllllll}\text { Croatia } & 35 & 33 & 38 & 25 & 22 & 25 & - & - & -\end{array}$

$\begin{array}{llllllllll}\text { Cuba } & 1 & 2 & 2 & 1 & - & - & - & 1 & 1 \\ \text { Cyprus } & 8 & 7 & 9 & 8 & 8 & 8 & 10 & 6 & 5\end{array}$

$\begin{array}{lrrrrrrrrr}\text { Czech Rep. } \quad 37 & 51 & 60 & 44 & 45 & 70 & 68 & 52 & 46\end{array}$

$\begin{array}{llllllllll}\text { Denmark } & 284 & 275 & 249 & 273 & 266 & 256 & 267 & 206 & 212\end{array}$

Dominican

Rep.

Ecuador

Egypt

Estonia

Ethiopia

Finland

France

Georgia

Germany

Greece

Guatemala

Honduras

Hong Kong

Hungary

Iceland

India

Indonesia

Irak

Iran

Ireland

Israel

Italy

Japan

Jordan

Kazahkstan

(CIS)

Kenia

Kirsigistan

Korea

Kuwait

Latvia

Lebanon

Lithuania

Luxemburg

Macao

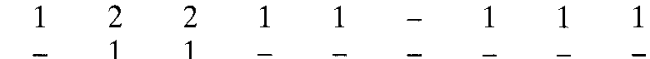

$\begin{array}{rrrrrrrrr}- & 1 & 1 & - & - & - & - & - & - \\ 13 & 23 & 20 & 11 & 12 & 12 & 13 & 9 & 8\end{array}$

$\begin{array}{lllllllll}17 & 17 & 8 & 7 & 6 & 5 & - & -\end{array}$ $\begin{array}{lllllllll}111 & 102 & 96 & 93 & 100 & 95 & 97 & 87 & 68\end{array}$ $\begin{array}{lllllllll}216 & 229 & 205 & 217 & 218 & 222 & 252 & 254 & 237\end{array}$

$$
\begin{array}{rrrrrrrrr}
5 & 3 & 2 & 2 & 1 & 1 & - & - & -
\end{array}
$$

$\begin{array}{lllllllll}488 & 435 & 416 & 363 & 350 & 315 & 319 & 262 & 220\end{array}$

$\begin{array}{lllllllll}138 & 145 & 138 & 126 & 125 & 131 & 118 & 122 & 82\end{array}$

$$
\begin{array}{llllllllll}
- & 1 & 1 & - & - & - & - & - & - \\
1 & 1 & 1 & - & - & - & - & - & -
\end{array}
$$

$$
\begin{array}{llllllllll}
1 & - & - & - & - & - & - & - & - \\
95 & 62 & 63 & 58 & 56 & 48 & 42 & 41 & 34
\end{array}
$$$$
\begin{array}{lllllllll}
95 & 62 & 63 & 58 & 56 & 48 & 42 & 41 & 34
\end{array}
$$$$
\begin{array}{rrrrrrrrr}
1 & - & - & - & - & - & - & - & - \\
14 & 14 & 9 & 8 & 9 & 6 & 7 & 8 & 6
\end{array}
$$

$$
\begin{array}{lllllllll}
3 & 1 & 1 & 1 & 1 & 1 & - & 2 & -
\end{array}
$$

$$
\begin{array}{lllllllll}
- & 2 & - & - & - & - & - & - & - \\
2 & 1 & 1 & 1 & 1 & - & - & - & -
\end{array}
$$$$
\begin{array}{rrrrrrrrr}
18 & 20 & 23 & 29 & 34 & 38 & 22 & 14 & 13
\end{array}
$$

$$
\begin{array}{lllllllll}
50 & 46 & 55 & 48 & 35 & 40 & 45 & 45 & 36
\end{array}
$$

$$
\begin{array}{rrrrrrrrr}
311 & 373 & 451 & 422 & 454 & 427 & 390 & 317 & 284
\end{array}
$$$$
\begin{array}{lllllllll}
141 & 112 & 86 & 76 & 62 & 52 & 49 & 40 & 32
\end{array}
$$

$$
\text { (1) }
$$




\section{Agenda for the 34th General Assembly of the European Association for the Study of Diabetes to be held in Barcelona, Spain, in Hall A - Sports Palace, Friday, 11 th September 1998 from 17.45-18.30 hours}

1. Minutes of the 33 rd General Assembly, Helsinki, Finland

2. Reports
a) President
b) Honorary Treasurer
Dr. M. Berger
c) Honorary Auditors
Dr. R.J. Heine
d) Honorary Secretary
Dr. P.J. Guillausseau
Dr. D. Pipeleers
e) Editor-in-Chief, Diabetologia
Dr. U. J. Eriksson
Dr. W. Waldhäusl

3. Elections
a) Vice President
in place of 1999-2002
Dr. P. A. Halban $(\mathrm{CH})$
retiring by rotation
b) Honorary Treasurer
Extension of term of office
by one year
c) Honorary Secretary
in place of 1998-2001
Dr. U.J. Eriksson (S)
d) Council Members
in place of
1999-2002
Dr. B.M. Frier (UK)
Dr. H. Ilkova (TR)
Dr. A.J. Scheen (B)
4. Postgraduate Education
Sub-Committee
Dr. A.J. M. Boulton (UK)

5. Study Groups

New: EASD Diabetic Foot Study Group

6. The European Foundation for the Study of Diabetes
7. Honorary Membership
Dr. E. Kohner (UK)
Dr. J.K. Davidson (USA)

8. Any other business 